\title{
Risk Assessment of Internal Control System and Its Effect on the Operations of Quoted Banks in the Nigerian Stock Exchange
}

\author{
Ozuomba Chidinma N., Ogujiofor Magnus Nkemjika, Enyeribe Onyekachi S. \\ Department of Accounting, Hezekiah University, Umudi, Imo State \\ Department of Accounting, Novena University, Ogume, Delta State \\ Department of Accountancy, Federal Polytechnic Nekede, Imo State
}

\begin{abstract}
Banks are more likely to fail from operational risk than from credit risk, and internal control at banks create operational risk losses. The objective of this study is to investigate internal control risk assessment and operational risk of quoted banks in Nigeria. 16 selected quoted banks in the Nigerian stock exchange from 2013-2017 were studied based on the 2012 banking reform on corporate governance by the then CBN governor Sanusi Lamido Sanusi's "Project Alpha Initiative" (PAI). Data were collected from banks published annual reports, CBN statistical bulletin, NDIC report, CBN fact book, company website and banks' Pillar III disclosure report for the relevant years sampled for analysis. The analysis carried out included pooled OLS regression, fixed and random effect and Hausman tests to determine the most suitable model for result interpretation. This was conducted with the aid of E-View 7 software. The findings shows that internal control risk assessment (ET and PQ) has positive significant effect on Operational risk (OPR). It was recommended that banks should ensure that internal control unit personnel are qualified and adequately trained to carry out banking activities as this will go a long way in reducing the risks from operations.
\end{abstract}

Keyword: Internal Control, Risk Assessment, Operational Risk

\section{Introduction}

One of the main reasons for banking failures which results in major financial loss and even bankruptcy is high risks taken by bank management on an excessive scale and inability of controlling them. The lack of an internal control system which duty is to keep the risks or major breakdowns within an existing internal control system under control pose a threat against the success of the banking sector. These operational risk has risen drastically in recent times. According to Moosa, (2007) Banks are more likely to fail from operational risk than from credit risk, It is believed that internal control at banks create operational risk losses, and many institutions with such losses are repeat offenders (Chernobai, Deumes and Knechel 2011).

Due to recent financial scandals and economic crisis, banking sector all across the globe has become vulnerable to fraudulent actions, rising uncertainties and development of more instruments have pressurized the banking organizations to look for the appropriate internal measures to transform their business organization as risk and uncertainty proof.

The banking sector consolidation exercise of 2004/2005 had some salutary impact on the Nigerian economy and led to the emergence of bigger banks which, before the global financial crisis, created a general belief that the banking sector was sound and growth would be encouraged. However, this sentiment proved misplaced following the outbreak of the global financial and economic crises of 2008/2009 and some interdependent factors that led to the manifestation of an extremely fragile financial system These Internal control weaknesses are revealed in operational losses in banks. The main objective of this study is to investigate the effect of internal control environment in curbing operational risk of quoted banks in Nigeria. This research work is anchored on Contingency theory. 


\section{Empirical Review}

Beretta and Bozzolan (2004) analyzed the risk disclosure of publicly listed Italian companies and argues that the quantity of disclosure is not a good proxy for the quality of disclosure, and that researchers need to focus on what is disclosed and found that companies disclose information about company strategy, financial structure of the company, and business processes. Much of the information does not explain how the risk might affect company performance, and when this is discussed, it is mainly how the company could be affected positively. Voluntary disclosure was used to discuss management's thoughts and expectations rather than risk-management actions taken for the future.

Lajili and Zégal (2005) investigate how management in publicly listed Canadian firms reports risk, which industries are reporting certain types of risk and corresponding risk management strategies. This article confirmed some findings in the Beretta and Bozzolan (2004) article. They found large differences between industries, with respect to how much risk information companies disclosed, which is different to the finding by Beretta and

Linsley and Shrives (2006) performed a similar analysis for British nonfinancial companies listed on the FTSE 100, which further developed the existing knowledge within this area. They found that the most commonly disclosed risks were "non-monetary/neutral/non-time specific risk management policy-financial risk disclosures and non-monetary/neutral/non-time specific policy- integrity risk disclosures". They found that there is a positive association between the company size and the volume of risk disclosure, which is different from earlier findings and that the number of non-monetary risk disclosures is significantly higher than the number of monetary risk disclosures

Linsley and Lawrence (2007) further analyzed this topic by looking at the readability of the risk disclosure in annual reports, and also whether management deliberately obscured bad news.

\section{Methodology}

The ex-post factor design type was used in this research work because it deals with historical facts and is designed to test an event that has already taken place. (Asika 2006; Agbadudu, 2002 cited in Ordu, Enekwe and Anyanwaokoro, 2014; Onwumere 2009). Secondary data was used in this work. The data machinery adopted for secondary data was Panel data set from banks published annual reports, NDIC report, CBN statistical bulletin, CBN fact books and banks' Pillar III disclosure report was utilized for this study. The panel covers a time frame of 5 years from 2013-2017 and a cross section of 16 banks from the population of 23 commercial Banks quoted in the Nigerian Stock Exchange as at 28 September 2018. However, Heritage bank, Savannah bank, Sky bank, keystone bank, Enterprise bank, Rand bank and Jaiz bank were eliminated based on availability of data, commencement of operation and Islamic bank with different characteristics from commercial banks. The sample size is justified based on the theory of Mugenda and Mugenda, (2003), that a good sample covers at least $10 \%-30 \%$ of the representative population. Thus, at $67 \%$ coverage the sample is a fair representation of the population and sufficient for this study. Multiple regression analysis technique was used in this study. Panel data regression model was adopted in order to control for individual unobserved heterogeneity, obtain more accurate results because it provides more observations and information to work with, it allows a follow up on individual dynamics and before and after effect can be easily estimated (Temple, 1999; Woodridge, 2002; and Hsiao, 2003 as cited in Alajekwu, 2018). Crosssectional and time series data are pooled in the regression to overcome the problem of insufficient degree of freedom. The Fixed Effects model (FEM) can be used to control the unobserved characteristics. Random effects model (REM) assumes that firm specific characteristics are not constant and the time effects are absent. The Hausman's specification test in Panel data models was conducted for fixed and random effects test of individual characteristics or time effect. 
Table 1: Operational definition of variables

\begin{tabular}{|l|l|l|l|}
\hline & & Variables & $\begin{array}{l}\text { Proxy } \\
\text { variables }\end{array}$ \\
\hline Dependent & Operational Risk: & 3 years Gross income @ 15\% divided by 3 & OPR \\
\hline Independent & Risk Assessment & $\begin{array}{l}\text { Employee turnover } \\
\text { Personnel Quality }\end{array}$ & $\begin{array}{l}\text { ET } \\
\text { PQ }\end{array}$ \\
\hline Control Variables & Bank Size & $\begin{array}{l}\text { Total no of bank in the year } \\
\text { Debt to total assets }\end{array}$ & BKS \\
& Leverage & LEV \\
\hline
\end{tabular}

Source: Author's conception, 2019

We indicate that there are bank-specific and other variables which could affect the dependent variable in one way or the other and must be controlled. These variables are bank size and Leverage.

Model: $o p r=(e t, p q, b k s, l e v)-(-1$

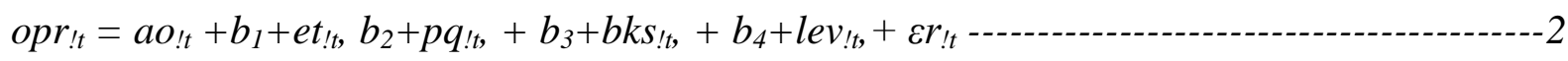

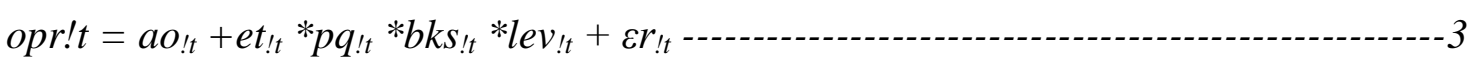

$\beta 0, \beta 1, \beta 2, \beta 3, \beta 4=$ coefficients

$\varepsilon i=$ error terms.

\section{Data Presentation and Analysis}

Table 2: Descriptive Analysis for Internal Control variables and Operational Risk variable from 2013-2017

\begin{tabular}{|l|l|c|c|c|c|}
\hline VARIABLES & \multicolumn{5}{|c|}{ COMMERCIAL BANKS } \\
\hline $\begin{array}{l}\text { Dependent } \\
\text { Variable }\end{array}$ & Operational Risk & 5.38 & 6.87 & 4.30 & 30.09 \\
\hline $\begin{array}{l}\text { Risk } \\
\text { Assessment }\end{array}$ & $\begin{array}{l}\text { Employee } \\
\text { turnover } \\
\text { (ET) (\%) } \\
\text { Personnel } \\
\text { Quality (PQ) }\end{array}$ & 68.85 & 14.10 & 29.00 & 47670.20 \\
\hline
\end{tabular}

\section{Source: Output generated using Eviews 7}

Risk Assessment is represented by two (2) proxy variables ET and PQ explained as follows: (i) Employee turnover measured percentage number of employee who have left dived by the percentage number of employee at the beginning of the year plus percentage number of employee at the end of the year divided by two showed a mean of 68.85 , maximum value of 14.10 , minimum of 29.00 and standard deviation of 47670.20. (ii) Personnel Quality measured by number of errors and bugs in software codes showing an average value of 7.55, maximum value of 14.10, minimum of 4.40 and standard deviation of 314.10.

\section{Normality Test}

Table 3: Result of Jargue- Bera Satistics for the test of normality

\begin{tabular}{|c|c|c|c|}
\hline VARIABLES & \multicolumn{3}{|c|}{ COMMERCIAL BANKS } \\
\hline & & Jarque-Bera & Prob. \\
\hline $\begin{array}{l}\text { Dependent } \\
\text { Variable }\end{array}$ & Operational Risk & 1.59 & 0.35 \\
\hline $\begin{array}{l}\text { Risk } \\
\text { Assessment }\end{array}$ & $\begin{array}{l}\text { Employee turnover (ET) (\%) } \\
\text { Personnel Quality (PQ) }\end{array}$ & $\begin{array}{c}3.94 \\
61.33\end{array}$ & $\begin{array}{l}0.13 \\
0.00\end{array}$ \\
\hline
\end{tabular}

\section{Source: Output generated using Eviews 7}


Jargue-Bera test of normality was used to identify the normality of error term. It is tested at 0.05 level of significance. The decision rule is to reject the null hypothesis, when P. value is less than 0.05 level of significance, otherwise, do not reject. The null hypothesis that error terms are normally distributed is rejected at 5\% level of significance for all the variables. Thus, error term is not normally distributed. The variable used in the study lacks normality for selected commercial banks quoted in the Nigerian Stock Exchange.

\section{Test for Multicollinearity}

Table 4: Correlation Matrix for test for multicollinearity in Operational Risk (OPR) and Control Variables (BKS and LEV) of the study.

\begin{tabular}{|r|r|r|r|}
\hline & OPR & BKS & LEV \\
\hline OPR & 0.729393 & & \\
\hline BKS & 0.065918 & 0.798290 & \\
\hline LEV & -0.218296 & -0.345518 & 0.747946 \\
\hline
\end{tabular}

\section{Source: Output generated using Eviews 7}

The test is conducted to check for suitability of the of the control variables in the model. Bank size and Leverage being control variables were tested for the existence of multicollinearity between variable using correlation matrixes as shown on table 4. The existence of collinearity shows that the regression cannot precisely intercept the influence of independent variable towards dependent variable (Gujarati and Porter, 2009). High pair wise correlation between two variables means there is a serious multicollinearity problem in the regression model. The level of high multicollinearity exist when the correlation between two variables exceed 0.8 (Gujarati and Porter, 2009). The result on table 4 showed correlation matrix for quoted banks. The highest pair wise correlation is 0.79 and the lowest is -0.21 . Since it is not more than 0.8 , the researcher conclude that the two variables do not suffer from serious multicollinearity and that the model in which the objective of the study is anchored is suitable for regression analyses.

H0: Risk assessment of internal control system and its effect on the operations

Table 5: Result of Risk assessment of internal control system and its effect on the operations

\begin{tabular}{|l|l|c|c|}
\hline & \multicolumn{3}{|c|}{} \\
\hline Independent Variables & Pooled OLS & $\begin{array}{l}\text { Fixed Effect } \\
\text { (Preferred Model) }\end{array}$ & Random Effect \\
\hline Constant (C) & $6.054713^{*}$ & $\mathbf{6 . 0 6 5 5 5 8}$ & $5.771321^{*}$ \\
Employee Turnover (ET) & 12.50767 & $\mathbf{9 1 2 . 0 0 3 7 6 )}$ & $(7.683438)$ \\
& $-0.001527^{*}$ & $\mathbf{- 0 . 0 0 1 5 6 4} *$ & $-0.000845^{*}$ \\
Personnel Quality (PQ) & $(-0.547416)$ & $\mathbf{( - 0 . 5 4 1 9 0 1 )}$ & $(-0.619636)$ \\
& $-0.112711^{*}$ & $\mathbf{- 0 . 1 1 2 8 6 0 *}$ & $-0.090053^{*}$ \\
Bank Size (BKS) & $(-3.444401)$ & $\mathbf{( - 3 . 3 5 3 2 2 3 )}$ & $(-1.595204)$ \\
& $-0.004921^{*}$ & $\mathbf{- 0 . 0 0 5 1 9 1 *}$ & $-0.040891^{*}$ \\
Leverage (LEV) & $(-0.081899$ & $\mathbf{( - 0 . 0 9 4 5 5 1 )}$ & $(-1.006760)$ \\
& $0.004921^{*}$ & $\mathbf{0 . 0 0 4 9 2 9 *}$ & $0.010973^{*}$ \\
\hline R-Squared & $(2.201661)$ & $\mathbf{( 2 . 1 4 4 0 9 3 )}$ & $(1.417564)$ \\
F-Statistics (Prob.) & $0.197572^{*}$ & $\mathbf{0 . 1 9 9 0 1 1 *}$ & $0.902741^{*}$ \\
Durbin Watson (DW) & $(0.002188)$ & $\mathbf{2 . 2 0 5 0 4 9 ( 0 . 0 3 6 9 8 3 )}$ & $29.31108(0.000000)$ \\
Hausman Test & 0.184976 & $\mathbf{0 . 1 8 1 0 0 3}$ & 1.549253 \\
& & $\mathbf{1 7 0 . 3 4 1 6 4 8 ( 0 . 0 0 0 0 )} * *$ & $0.526373(0.9709)^{* *}$ \\
\hline
\end{tabular}

Legend: Dependent variable: operational risk (OPR), significant at *1\%, **5\%

Source: Extract from result presented on Appendix 8, Table 19d

Two proxy variables representing the model on the effect of risk assessment on operational risk were employed to test the hypotheses of this study. From the regression analysis result as shown on table 5, it is observed that $r^{2}$ for pooled OLS, fixed effect and random effect are 0.19 and 0.19 respectively and that of 
random effect is 0.90 that is, for each model used 19\%, 19\% and $90 \%$ of the dependent variable (OPR) is explained by the Independent variables: ET and PQ and control variable BKS and LEV. The coefficient value of the independent proxy variable: LEV is positively correlated with the dependent variable OPR. While ET, PQ and BKS are negatively correlated with the dependent variable OPR. This implies that any increase/decrease in the independent variables will result in an increase/decrease in the dependent variable. From the further test conducted, the redundant (Hausman) fixed effect model showed a value of 170.341648 with a probability of 0.0000 and the Hausman random effect model showed a value of 0.526373 and a probability of 0.9709 . The fixed effect is preferred because the probability of the Chi. Square is less than $0.05 \%$ level of significance. From the result obtained, we accept the alternate Hypotheses which states that risk assessment has a significantly negative effect on operational risk of quoted banks in Nigeria and reject the null hypothesis. The variables employed showed negative value that is, any increase/decrease in any of the independent variables will lead to an increase in the dependent value except for leverage that is positively significant.

Durbin Watson is close to 2.0 as such the variables are highly significant. Probability values of the coefficient at $0.1-0.7$ implies that the regression parameters are significantly different from zero and the probability for the variables reveal a normal curve. The F-statistics is 29.31108 to show that the coefficient of explanatory variables has a significant effect on operational risk in the annual financial reports of quoted companies in Nigeria. From the result obtained, we accept the alternate Hypothesis which states that risk assessment has a significantly negative effect on operational risk of quoted banks in Nigeria and reject the null hypotheses

\section{Findings}

The main objective of this study was Risk assessment of internal control system and its effect on the operations of quoted Banks in the Nigerian stock exchange. Secondary data was sourced from annual reports, banks websites, CBN statistical bulletin, CBN fact book, NDIC report and banks pillar III disclosures. Using a sample of 16 quoted firms in the period 2013 to 2017; the study first provided both empirical and statistical evidence on the aggregate impact of the two proxy variables on the internal control assessment of operational risk of quoted banks in Nigeria. Secondly, the study also provides evidence that internal control risk assessment have a significant positive impact on operational risk of quoted banks in Nigeria. While Bank size has a significantly negative effect on operational risk of quoted banks in Nigeria. It was concluded that internal control risk assessment has a significantly positive effect on operational risk in the banking sector. It was recommended that banks should ensure that internal control unit personnel are qualified and adequately trained to carry out banking activities as this will go a long way in reducing the risks from operations.

\section{References}

[1] Asika, N. (2006). Research Methodology in Behavioural Sciences. $2^{\text {nd }}$ Edition, Longman Nigeria PLC.

[2] Alajekwu, U. B. (2018). Dividend policies and performance of quoted firms in Nigeria. Unpublished Doctoral thesis presented at Nnamdi Azikiwe University Awka.

[3] Beretta, S. and Bozzolan, S. (2004). A framework for the analysis of firm risk communication, International Journal of Accounting, 39/. 265-288.

[4] Cebenoyan A.S. \& Strahan, P.E. (2004). Risk management, capital structure and lending at banks. Journal of Banking \& Finance 28(1), 19-43.

[5] COSO (Committee of Sponsoring Organisations of the Treadway Commission) (1992). Internal Control-Integrated Framework. New York: AICPA.

[6] Gujarati, D. N. and Porter, D.C. (2009). Basic Econometric. $5^{\text {th }}$ edition. Kuala Lumpur. McGraw-Hill Higher Education.

[7] Linsley, P. M., \& Lawrence, M. J. (2007). Risk reporting by the largest UK companies: readability and lack of obfuscation. Accounting, Auditing \& Accountability Journal, 20 (4).

[8] Linsley, P. M., and Shrives, P. J. (2006). Risk reporting: a study of risk disclosures in the annual reports of UK companies. British Accounting Review, 38/, 387-404.

[9] Lajili, K. and Zeghal, D. (2005). A Content Analysis of Risk Management Disclosures in Canadian Annual Reports. The Canadian Journal of Administrative Sciences, 22/2, 125-142 
[10] Moosa, I. A. (2007). Operational Risk: A Survey. Financial Markets, Institutions, and Instruments, 16, 167-194.

[11] Mugenda O.M. and Mugenda, A. G. (2003). Research Methods: Quantitative and Qualitative Approaches. Nairobi press, African Center for Technology studies (ACTS).

[12] Onwumere, J.U.J. (2009). Business and economic research methods. Enugu: Vougasen publishers. 29-67.

[13] Ordu, M.M., Enekwe, C.I. and Anyanwaokoro, M. (2014). Effect of Dividend payment on the market price of shares: A study of quoted firms in Nigeria. IOSR Journal of Economics and Finance, 5(4) 49-62. 